\title{
Editorial: The German Debate on International
}

\section{Investment Law}

\author{
Mounting Criticism of International Investment Law in Germany; \\ Policy Space under CETA, the German Constitution and EU Law; \\ 2014 in Retrospect; In This Issue
}

\section{Mounting Criticism of International Investment Law in Germany}

The future of international investment law and investor-State arbitration remains highly debated. This is particularly true in respect of the investment chapters in the Transatlantic Trade and Investment Partnership (TTIP) currently under negotiation between the European Union (EU) and the United States and the Comprehensive Economic and Trade Agreement (CETA) between the EU and Canada, of which a final text has been agreed upon in September 2014. ${ }^{1}$

In reaction to the publication of CETA's investment chapter, which is widely regarded as a reflection of the EU Commission's thinking on investment protection more generally, ${ }^{2}$ and is possibly a blueprint for TTIP, a vivid debate has ensued in Germany with investor-State dispute settlement is severely criticized. Opposition to CETA's investment chapter comes from the Green Party, the socialist party Die Linke, as well as labor unions and various non-governmental organizations; but also the Social Democrats, whose party leader Sigmar Gabriel is, as Federal Minister for Economic Affairs and Energy, in charge of international economic agreements, are critical of investor-State arbitration in CETA.

The debate continues, but for now the signing of CETA, originally scheduled to take place at the EU-Canada summit in September 2014, has been put off. Is Germany, the country that not only has concluded the first bilateral investment treaty (BIT) in 1959 but also has the densest network of BITs worldwide, as some fear, joining the coalition of critics and fundamentally reversing its international investment policy?

1 The text of CETA, including annexes, is available for download at <http://trade.ec.europa.eu/ doclib/html/152806.htm > accessed 17 December 2014.

2 See the various contributions to the Special Issue of the Journal of World Investment and Trade on 'The Anatomy of the (Invisible) EU Model BIT', edited by Marc Bungenberg and August Reinisch in (2014) 15 JWIT 375-704. 
In my view, the matter is not quite that tragic. Above all, the current debates in Germany must be put into context to become understandable. That context is first and foremost Vattenfall's arbitration under the Energy Charter Treaty regarding Germany's nuclear power phase-out (Vattenfall II). ${ }^{3}$ Yet, just pointing to the fact that Germany has now joined the ranks of respondents is too simple an explanation for the current criticism. Two earlier investment treaty arbitrations, a little-known UNCITRAL proceeding under the Germany-India BIT initiated in the late $1990 \mathrm{~s}^{4}$ and Vattenfall I $v$ Germany, which involved a dispute about environmental standards for a coal-fired power plant in the City of Hamburg, ${ }^{5}$ had no significant political repercussions.

The Vattenfall II case, however, is special because it involves more than the challenge of a politically sensitive legislative measure; much more: the nuclear power phase-out touches on an issue that has marked Germany's social and political culture over the past three and a half decades like no other issue apart from German reunification. The Green movement would have been unthinkable in its present form without opposition to nuclear power and the peace movement during the Cold War is likely to have been significantly different.

The entire political and social landscape in Germany, in other words, has been so deeply influenced by the struggle against nuclear power that Vattenfall II, and with it investor-State arbitration generally, is seen as a challenge to a fundamental social and political settlement and hence to democracy more generally. Add to that an at best half-way informed press that understands little even of the basics of international investment law and investor-State arbitration, and you have the perfect storm of public skepticism vis-à-vis investorState arbitration.

Notwithstanding the wide-spread criticism, it is important to note that no official government position has been taken that would reverse Germany's stance on international investment law and investor-State arbitration generally. In fact, criticism at present is (still) largely limited to investment disciplines in agreements with other developed economies. What is more, rather than blind and predetermined attacks against established features of international investment law, we are seeing the beginning of a debate that - beyond the inevitable political saber-rattling - tries to be objective, representative, and open.

3 Vattenfall $A B$ and others $v$ Federal Republic of Germany, ICSID Case No ARB/12/12 (registered 31 May 2012).

4 Sanchetiv Federal Republic of Germany, UNCITRAL, Award (6 June 2001) (proceedings terminated because Claimant failed to pay advances on costs) (award on file with author).

5 Vattenfall AB, Vattenfall Europe AG, Vattenfall Europe Generation AG \& Co KG v Federal Republic of Germany, ICSID Case No ARB/og/6, Award (11 March 2011). 
In fact, core actors in Germany, above all the Ministry for Economic Affairs and Energy, seem determined to create a rational and well-informed framework for the debate on international investment law and investor-State arbitration that is representative of all major stakeholders. Thus a Council on TTIP with representatives of German industries, labor unions, churches, consumer associations, environmental groups, agricultural production, local communities, and transparency international, amongst others, has been created to advise the Ministry. ${ }^{6}$ Furthermore, the Ministry commissioned a study on whether the investment chapter in CETA restricted the legislator's policy space beyond existing restrictions under Germany constitutional law and EU law, on which I report below. All of this has the purpose to rationalize the debate and provide a basis on which political institutions, social interest groups, and the public at large can form an opinion on investor-State arbitration.

In sum, the debate in Germany about international investment law, in my view, is a positive development because only the type of public debate we are now seeing there will enable international investment law to develop, on a solid democratic basis, into its next phase, namely that of large-scale trade and investment agreements between major economic blocks and regional organizations, whether between the EU and the United States or between the EU, China, India, and ASEAN. International investment law must be democratically endorsed - and that is why similar debates should be encouraged more generally, rather than stalled.

\section{Policy Space under CETA, the German Constitution and EU Law}

In the context of the discussions on CETA, an important question is whether CETA's investment chapter reduces Germany's 'policy space', in particular that of the legislator, beyond existing limitations under German constitutional law and EU law. If it did, this would have been a clear sign that the claims of critics about the reduction of policy space by investment treaties hold true. Indeed, the claim that investment treaty disciplines afford better protection is widespread; but studies showing this by comparing investment treaty disciplines with how foreign investment is protected under domestic constitutional law and other international instruments are largely amiss. ${ }^{7}$ For this reason, and in

6 For more information see <http://www.bmwi.de/DE/Ministerium/beiraete,did=639536 .html $>$ accessed 21 October 2014.

7 For an exception see, for example, Lise Johnson and Oleksandr Volkov, 'Investor-State Contracts, Host-State "Commitments" and the Myth of Stability in International Law' (2013) 24 Am Rev Intl Arb 361. 
order to have a basis for making decisions about the possible consequences of CETA, the German Federal Ministry for Economic Affairs and Energy commissioned a legal opinion on the impact of the investment disciplines under CETA on the legislator's policy space that I had the honor to render. ${ }^{8}$

This is what I concluded in the executive summary:

The international legal obligations in CETA that grant protection to investments of Canadian investors impose restrictions on the legislator that are independent of German constitutional and State liability law as well as of EU law. CETA grants - albeit subject to extensive exceptions market access, national treatment and most-favored-nation treatment to Canadian investors, protects existing investments against narrowly defined legislative interventions (especially uncompensated expropriations and measures tantamount to expropriation, violations of fair and equitable treatment and full protection and security) and contains provisions to ensure the free transfer of capital. Violation of these rules may be invoked in interstate arbitrations and - albeit subject to important restrictions in relation to market access, in the area of financial regulation, and concerning taxation - in investor-State arbitrations.

Yet, CETA hardly imposes restrictions on the legislator's regulatory space that go beyond those already in existence under constitutional and EU law. Only the right to national and most-favored-nation treatment results, to the extent none of the numerous exceptions applies, in a substantial improvement of the legal protection of Canadian investors. Through CETA they are granted protection that is, as regards market access and protection of existing investments, equivalent to that enjoyed by domestic investors under the constitution's fundamental rights and by EU investors under fundamental freedoms and fundamental rights granted under EU law. This reduces the legislator's policy space insofar as discriminations of foreign investors due to their Canadian nationality become inadmissible. This notwithstanding, the numerous exceptions that CETA contains significantly narrows the right to equal treatment both for Canadian investors in Germany, as well as for German (and other European) investors in Canada.

8 The complete study (in German) is available as Stephan W Schill, Auswirkungen der Bestimmungen zum Investitionsschutz und zu den Investor-Staats-Schiedsverfahren im Entwurf des Freihandelsabkommens zwischen der EU und Kanada (CETA) auf den Handlungsspielraum des Gesetzgebers (August 2014) <http://www.bmwi.de/BMWi/Redaktion/PDF/C-D/ceta -gutachten-investitionsschutz $>$ accessed 16 October 2014. 
As regards the protection of existing investments against interferences by the legislator other than discriminatory treatment, CETA falls short of the protection granted by German constitutional law and EU law. In relation to legislative measures, the right to fair and equitable treatment under CETA is essentially limited to a prohibition of manifestly arbitrary measures and a minimum level of protection of legitimate expectations. By contrast, the protection granted by the concept of the rule of law ('Rechtsstaatsprinzip') and the principle of proportionality under the German constitution are more comprehensive. Similarly, the provisions in CETA protecting against direct and indirect expropriation are not farther-reaching than parallel protections under the German constitution. In addition, the legislator's policy space is expressly protected against limitations through a variety of exceptions in CETA, including for the protection of national security, the environment, or public health, as well as exceptions regarding taxation and the regulation of financial markets.

Differences between constitutional law and EU law, on the one hand, and the provisions protecting investments under CETA's investment chapter, on the other hand, exist with respect to the legal consequences of breaches of the respective provisions. However, divergences in this respect are essentially due to structural differences of the legal regimes in question. Unlike under constitutional law and EU law, the legal consequences of a breach of CETA are limited to compensation and damages; the repeal or the adoption of a legislative measure cannot be demanded. As a substitute for the absence of a right of an investor to demand the establishment of a CETA-compliant state of affairs, CETA permits an immediate claim for compensation and damages; it thereby deviates from the situation under constitutional law where compliance with primary obligations takes precedence over the State's liability for damages. Yet, since the restrictions CETA imposes on legislative action are less imposing than those under constitutional law and EU law, the liability risk is manageable. Similarly, the standard for calculating compensation and damages, including interests, only marginally deviates from German State liability law. Yet, depending on the circumstances, the costs for pursing claims in investor-State arbitration may be higher than in proceedings before domestic courts.

An important difference between CETA and constitutional law and EU law concerns the enforcement mechanism in investor-State arbitration proceedings. Yet, access to arbitration is subject to high procedural hurdles and is only available for a narrow class of claims. The risk that arbitral tribunals under CETA further develop the applicable legal standards, 
and thereby extend State liability, are mitigated by institutional mechanisms. This cannot be seen as a limitation of the legislator's policy space that goes beyond constitutional law and EU law.

Overall, CETA essentially imposes no restrictions on the legislator that go beyond existing restrictions under constitutional law or EU law. On the contrary, in central aspects CETA lags behind the level of investment protection offered under constitutional law and EU law. Concerns in respect of liability risks of the Federal Republic of Germany or of the limitation of the legislator's policy space because of the provisions on the protection of investments in CETA are therefore negligible. Rather, the relatively low level of international investment protection puts the value of the investment chapter in CETA for the protection of German and European investors in Canada into question.

Whether Canada and the EU can live with this investment chapter both in respect of their defensive interests as capital-importing countries and their offensive interests as capital-exporting countries is a political question for which technical expertise cannot have an answer. My conclusions do suggest, however, that the investment chapter in CETA is neither the anti-democratic, policy-space-eating beast that some opponents of investment treaty protections evoke, nor does it represent the same high level of investment protection contained in most hitherto existing Member States' BITs. My conclusions may not sit easily with everybody and there may also be disagreement on my evaluations of investment law, German constitutional law, and EU law, given that all three bodies of law are based on principles that require an appreciation and weighing of competing interests. Yet, instead of raising charges of personal bias against me (which already has occurred), or continuing to scaremonger about the wide-ranging impact of investment treaty disciplines on domestic policy space, my request would be that opponents come forward with substantive analyses themselves, showing where investment disciplines apart from the field of non-discrimination - really are more restrictive than existing constitutional or EU law disciplines, whether in Germany or elsewhere.

At the very least, I hope that studies such as the one I conducted on Germany are the start of a more rational political as well as professional debate in respect of all involved disciplines, that is, investment law, EU law, and constitutional law. Moreover, I hope that similar studies will be conducted in relation to other domestic constitutional systems. This could give rise to a truly countryoverarching debate on how investment law, supranational legal regimes, such as EU law, and domestic constitutional law relate to each other, thereby 
enabling a well-informed and rational discourse on how investor-State relations can and should be structured.

\section{4 in Retrospect}

The publication of the first issue in 2015 is an occasion to look back at 2014, the first year under my editorship. Statistics are the natural way to approach this - whether the content has been appealing, interesting, stimulating, is for you, the reader, to judge. In 2014, JWIT has published a total of 1,124 pages, containing 28 articles (of which 14 were part of a Special Issue on the EU's international investment policy and 7 of a Special Issue on investment law and sustainable development), 17 case comments, 3 book review essays, 11 book reviews, and 3 editorials. The topics covered included investment and trade law, EU law, WTO law and commercial arbitration. This is an encouraging start for the new JWIT.

A new year is also the time to say 'thank you'. I would like to thank my editorial team (Editorial Office, Associate and Assistant Editors), without whom running the Journal would be impossible, as well as the members of the Editorial Board and of the Editorial Advisory Board for their commitment and support. Furthermore, thanks are due to all those helping the Journal in pursuing its mission by cutting out time in their busy schedules for peer reviews. Apart from members of the Board, the following served as peer reviewers in the past year: Mathias Audit, Perry Bechky, Axel Berger, Christina Binder, Jonathan Bonnitcha, Anatole Boute, Chi Carmody, Lorenzo Cotula, Omaia Elwan, Tarcisio Gazzini, Lukasz Gruszczynski, Pasha Hsieh, Ursula Kriebaum, Meredith Lewis, Mohamed Mattar, Makane Mbengue, Gregory Messenger, Tim Meyer, Peter Muchlinski, Shin-yi Peng, Lauge Poulsen, Michele Potestà, Mavluda Sattorova, Engela Schlemmer, Yulia Selivanova, Federica Violi, Riekie Wandrag, and Julia Ya Qin. This service is vital to the Journal and is gratefully acknowledged.

\section{In This Issue}

This issue kicks off with a detailed account of the negotiations of the United Nations Code of Conduct on Transnational Corporations (and various related instruments) that started in the 1970s. It is based both on the first-hand experience of its author, Karl P. Sauvant, who has accompanied the negotiations as a member of the United Nations Centre on Transnational Corporations, and interviews with many of the negotiators. Sauvant's piece is a fascinating 
account of the promises and difficulties of an instrument that attempted to put into place a far-reaching regulatory approach to foreign investment relations that contained, unlike the current, protection-based system, rights and responsibilities of host countries and transnational corporations. As Sauvant argues, the experience with the Code negotiations is not only of purely historical interest, but should inform current efforts at reforming the international investment regime.

In the second article, Sotonye Frank provides a critical analysis of the presumptions on which the need for including stabilization clauses in contracts with developing countries in the natural resources sector is based: first, the existence of competition of developing countries for foreign direct investment; and second, the higher level of political risk in these countries. Frank argues that neither presumption is true as such and that, hence, stabilization clauses are much less important for developing countries to attract foreign investment than often assumed. His article and the arguments he provides should further fuel the already vivid debate about stabilization clauses.

The third article reproduces Michael Trebilcock's Robert Hudec Lecture at the 2014 Biannual Conference of the Society of International Economic Law in Bern. Tracing the role of developing countries in the world trading system and the evolving legal framework for their participation, he attributes the paralysis of the Doha Development Round to the failure of the WTO in advancing an appropriate interface between trade and development. As a way forward, Trebilcock advocates for a fundamental rethinking of the orientation of the multilateral trading system that reconciles international trade law and policy and development theory. The key, in his view, is for trade law to become more flexible, contextual and tailored in order to permit both the implementation of development objectives and enhanced cooperation through plurilateral and preferential trade agreements, without giving up the WTO's claim to arrive at a universal, non-discriminatory regime.

The fourth article by Benn McGrady presents an account of how the WTO principle of non-discrimination has been applied by the Appellate Body in its recent rulings in US-Cloves Cigarettes, US-Tuna II, US-COOL and EC-Seal Products to measures involving distinctions regarding the import and sale of certain products that aimed at achieving legitimate regulatory objectives, such as the protection of public health, consumers, or animal welfare. Most interestingly, McGrady examines to which extent these WTO decisions may impact the application and interpretation of the principle of non-discrimination in international investment law. His analysis shows the great potential for 
cross-fertilization between trade and investment law, but also cautions against all-to-easy transposition.

To close, in the case comments section, Julian Mortenson deals with the jurisdictional decision in the NAFTA-dispute in Apotex $v$ United States, in particular the way the notion of 'investment' was narrowed. The book review section contains a review essay by Regis Simo on a book edited by Susy Frankel and Meredith Lewis on Trade Agreements at a Crossroads and a review of S.I. Strong's book on Class, Mass, and Collective Arbitration in National and International Law.

With that, all the best for 2015 and keep following JWIT!

Stephan W. Schill 